\title{
The Utilization of Selected Threatened or Protected Plant Species; A Case of Limpopo Province, South Africa
}

\author{
Marula Rasethe ${ }^{1, *(\mathbb{D}}$, Martin Potgieter $^{1} \mathbb{D}$ and Michèle Pfab ${ }^{2}$ \\ 1 Department of Biodiversity, University of Limpopo, Private Bag X1106, Sovenga 0727, South Africa; \\ martin.potgieter@ul.ac.za \\ 2 Biodiversity Assessment and Monitoring, South African National Biodiversity Institute (SANBI), \\ Private Bag X101, Silverton 0184, South Africa; M.Pfab@sanbi.org.za \\ * Correspondence: truimph.rasethe@gmail.com; Tel.: +27-7-6784-3608
}

check for updates

Citation: Rasethe, M.; Potgieter, M.; Pfab, M. The Utilization of Selected

Threatened or Protected Plant Species; A Case of Limpopo Province, South Africa. Sustainability 2022, 14, 1073. https://doi.org/10.3390/su14031073

Academic Editors: Richard

A. Niesenbaum and Carl

Ronald Carroll

Received: 4 July 2021

Accepted: 28 September 2021

Published: 18 January 2022

Publisher's Note: MDPI stays neutral with regard to jurisdictional claims in published maps and institutional affiliations.

Copyright: (C) 2022 by the authors. Licensee MDPI, Basel, Switzerland. This article is an open access article distributed under the terms and conditions of the Creative Commons Attribution (CC BY) license (https:// creativecommons.org/licenses/by/ $4.0 /)$

\begin{abstract}
In Limpopo Province, harvesting plants for herbal use by traditional health practitioners and ordinary people is an everyday practice. The study investigated the utilization of the following Threatened or Protected Plant-listed species (TOPS): Alepidea amatymbica Eckl. \& Zeyh., Brackenridgea zanguebarica Oliv., Dioscorea sylvatica Eckl., Drimia sanguinea (Schinz) Jessop, Siphonochilus aethiopicus (Schweinf.) B.L.Burtt and Warburgia salutaris (G.Bertol.) Chiov. in Limpopo Province, South Africa. A total of 333 participants were interviewed in this study, across the five districts of the Limpopo Province. Results indicate that traditional health practitioners (THPs) and community members (CMs) use these species exclusively for medicinal purposes. Remedies were often prepared using the underground parts of the plants, which were purchased chiefly from muthi shops-shops trading in both indigenous and exotic plant and animal material used for witchcraft and/or healing. Just over $58.4 \%$ of respondents indicated that they purchase material from muthi shops due to their scarcity in local communal lands. In contrast, nearly $40 \%$ of participants disclosed that they harvest material from open access land. Only $1.6 \%$ of participants sourced these plants from their home gardens. The preference for underground parts and species rarely cultivated in home gardens will lead to extinction of wild populations unless users switch to alternative parts for sustainability.
\end{abstract}

Keywords: ethnobotany; traditional medicine; indigenous plants; TOPS-listed plants

\section{Introduction}

The use of traditional medicine to treat various diseases has been part of human culture since ancient times [1]. Despite the influx of western treatments, the use of herbal remedies is still prominent in South Africa, with an estimated 27 million South Africans self-medicating with traditional medicine at some stage in their lives [2]. Furthermore, in 2010, approximately 250,000 to 400,000 registered traditional health practitioners were consulted by over $80 \%$ of the population [3]. Several literature sources [4-6] confirm that both traditional health practitioners and laypeople mostly prefer plants to animal products for the preparation of their medicine. Makueti et al. [7] and Semenya and Maroyi [8] also noted that plant-based materials are preferred, irrespective of their conservation status.

As is common in other provinces of South Africa, in the Limpopo Province, harvesting of plants for herbal use by both traditional health practitioners (THPs) and ordinary people is an everyday practice [9]. Ethnobotanical studies [10,11] conducted in this province indicated that medicinal plants are mostly harvested from natural environments. These same studies briefly highlighted that such harvesting includes the collection of plants that are officially protected by legislation, such as the Threatened or Protected species (TOPS) Regulations. According to Section 56 of the (National Environmental Management: Biodiversity Act) No. 107 of 2004, TOPS plants are listed and restricted activities enforced to ensure that the species are managed sustainably. Harvesting of these species in the Limpopo Province, especially by THPs, is usually triggered by the high demand for 
medicinal preparations [12]. Therefore it is significant and pertinent that a comprehensive ethnobotanical survey is undertaken to determine the extent of reliance of THPs and ordinary community members on TOPS-listed plants in this province.

The study investigated the utilization of the following TOPS-listed plant species: Alepidea amatymbica, Brackenridgea zanguebarica, Dioscorea sylvatica, Drimia sanguinea, Siphonochilus aethiopicus and Warburgia salutaris in different districts of the Limpopo Province by: (1) identifying the various uses of TOPS-listed plant species, including disease categories and ailments treated with these species, (2) investigating aspects related to indigenous medicinal remedies such as method of herbal preparation, parts used in remedy preparation, and mode of administration, and (3) determining factors related to plant collection such as a source of plant material and perception of users on their local availability. The results will contribute to the compilation of a database regarding the TOPS-listed plant species in the Limpopo Province of South Africa.

\section{Materials and Methods}

\subsection{Study Area}

The study areas were located in the five districts of the Limpopo Province of South Africa, namely Capricorn, Mopani, Sekhukhune, Vhembe, and Waterberg districts (Figure 1). The Limpopo Province falls within the savanna biome, which compromises a combination of trees, shrubs and grasses and is characterized by a diverse flora with useful plant species that local people utilize to meet their livelihood needs [13].

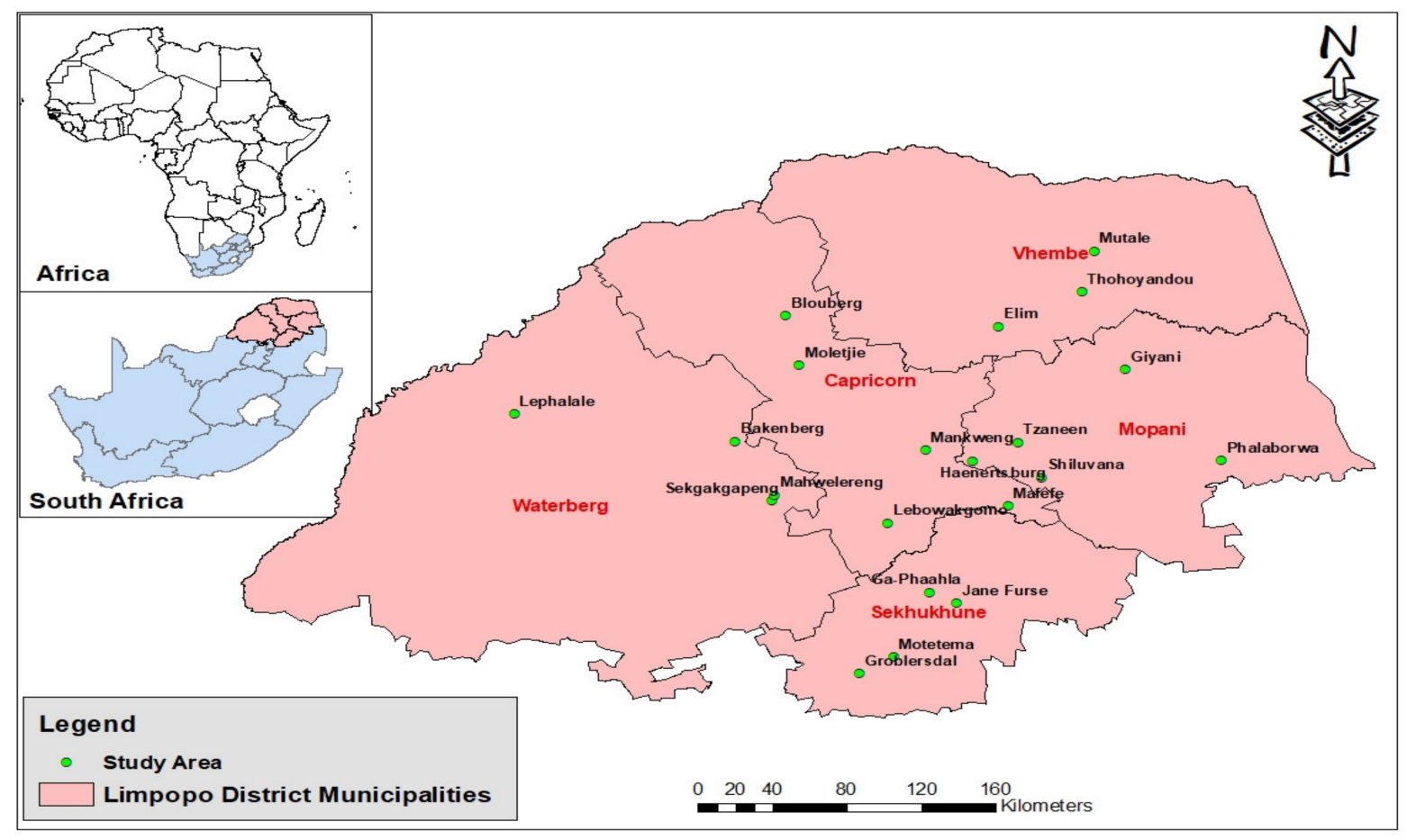

Figure 1. Study areas surveyed in the five districts of the Limpopo Province, South Africa.

\subsection{Data Collection}

A reconnaissance field trip was conducted in March 2014 in the five districts of the Limpopo Province; to explain the goals of the research project, to obtain permission to conduct this study within the areas, and also to meet with locals (traditional healers and community members) to request them to participate in the study. Sample selection of participants was random for community members and snowball for traditional healers with the help of local traditional leaders [14], in areas where the species are known to occur. The participants were shown colorful photos of the species and asked for their 
vernacular names, to compare with names recorded in the literature. Only plant species that participants were familiar with were selected for the study.

Formal surveys were conducted during the period January-December 2015. Semistructured questionnaires were used to gather information from 110 community members (CMs) and 180 traditional health practitioners (THPs). A total of 290 participants were interviewed for the study (Table 1).

Table 1. Quantity of participants interviewed per district.

\begin{tabular}{ccccccc}
\hline \multirow{2}{*}{ Groups } & \multicolumn{5}{c}{ Districts } & \multirow{2}{*}{ Total } \\
\cline { 2 - 6 } & Capricorn & Sekhukhune & Mopani & Waterberg & Vhembe & \\
\hline THPs & 40 & 40 & 40 & 40 & 20 & 180 \\
\hline CMs & 25 & 25 & 25 & 25 & 10 & 110 \\
\hline Total & 65 & 65 & 65 & 65 & 30 & 290 \\
\hline
\end{tabular}

\subsection{Species Utilization}

The six plant species in the current study are threatened according to the criteria outlined by the South African National Red Data List of plants [15]. The species conservation status follows: Alepidea amatymbica (Endangered A2d), Brackenridgea zanguebarica (Critically Endangered A2ad; B1ab (ii,v)), Dioscorea sylvatica (Vulnerable A2cd), Drimia sanguinea (Near Threatened A2d), Siphonochilus aethiopicus (Critically Endangered A4acd) and Warburgia salutaris (Endangered A2acd).

Data relating to the use of the above-mentioned species was gathered through semistructured questionnaires submitted to CMs and THPs, who use the six selected species. The questionnaires were designed to capture information on the various ailments treated and the medicinal remedies prepared by both THPs and CMs. The method used by Hutchings [16] to categorize ailments was also used; they were grouped by symptoms. For example, high blood pressure, swollen legs and stroke were grouped under circulatory systems because both conditions can affect the normal blood flow.

Using the same questionnaires, participants were asked about plant parts harvested, and the methods used to prepare the herbal remedies. According to Quinlan [17], this kind of questionnaire is an accurate, simple, efficient method, and a quick way to collect data for a large sample size.

\subsection{Medicinal Application of Plants}

Based on individual's knowledge with regard to the medicinal application, disease categories such as circulatory, dermatological, digestive, endocrine, immune, nervous, parapsychological, reproductive, respiratory, sexually transmitted infections and skeletomuscular were recorded. Furthermore, the investigated plant species used by traditional practitioners and community members to treat the given above disease categories were documented. Although several disease categories were mentioned, the focus fell only on the most treated four.Within each category, the focus was only on the three most treated ailments. This focus ensured a concise representation of broad data collected without confusion.

\subsection{Plant Collection}

Information related to the collection of plants by CMs and THPs was gathered using a data sheet. The participants were requested to indicate the source (area) of plant material. For example, whether they collect from home gardens or the wild, or whether they purchase from muthi shops or medicinal plant traders. Participants who collected from the wild were further queried on their perceptions on species availability. 


\subsection{Ethical Considerations}

Prior informed consent was obtained from CMs and THPs to conduct this study within their area of jurisdiction. As required by the University of Limpopo's ethics committee, participants gave their informed consent for the publication of all results and any accompanying images before commencing with the interview schedules.

\subsection{Data Analysis}

Data was analysed using Microsoft Excel 2000. Information collected through a semi-structured questionnaire and field observations were tabulated into meaningful patterns and summarised using descriptive statistics such as frequencies and percentages as recommended by Pérez-Vicente and Ruiz [18].

\section{Results}

\subsection{Species Utilization}

The six investigated plant species, namely; Alepidea amatymbica, Brackenridgea zanguebarica, Dioscorea sylvatica, Drimia sanguinea, Siphonochilus aethiopicus and Warburgia salutaris, were used medicinally in all five districts. In general, THPs used these species more than CMs (Table 2). This study noted that most CMs were not interested in using medicinal plants, they could not remember the medicinal application of a single plant. It was found that the species most commonly used by THPs and CMs were; S. aethiopicus, W. salutaris and D. sanguinea (Table 2). The species used the least were D. sylvatica and B. zanguebarica. It was noted that in almost every household THPs and CMs knew and used S. aethiopicus, it is a custom practiced regardless of religious believes.

Table 2. Frequency of use of investigated TOPS-listed species as cited by community members and traditional health practitioners.

\begin{tabular}{|c|c|c|c|c|c|c|c|c|c|c|c|c|c|}
\hline \multirow{3}{*}{ Species } & \multirow{3}{*}{ Participants } & \multicolumn{10}{|c|}{ Districts } & \multirow{2}{*}{\multicolumn{2}{|c|}{ Total }} \\
\hline & & \multicolumn{2}{|c|}{$\mathrm{C}$} & \multicolumn{2}{|c|}{$S$} & \multicolumn{2}{|c|}{$\mathbf{M}$} & \multicolumn{2}{|c|}{$\mathbf{W}$} & \multicolumn{2}{|c|}{ V } & & \\
\hline & & No & $\%$ & No & $\%$ & No & $\%$ & No & $\%$ & No & $\%$ & No & $\%$ \\
\hline \multirow{2}{*}{ Alepidea amatymbica } & CMs & 0 & 0 & 5 & 20 & 7 & 28 & 3 & 12 & 0 & 0 & 15 & 14 \\
\hline & THPs & 23 & 57.5 & 33 & 82.5 & 33 & 82.5 & 28 & 70 & 4 & 20 & 121 & 67 \\
\hline \multirow{2}{*}{$\begin{array}{c}\text { Brackenridgea } \\
\text { zanguebarica }\end{array}$} & $\mathrm{CMs}$ & 0 & 0 & 3 & 12 & 2 & 8 & 1 & 4 & 0 & 0 & 6 & 6 \\
\hline & THPs & 19 & 47.5 & 13 & 32.5 & 27 & 67.5 & 13 & 32.5 & 16 & 80 & 88 & 49 \\
\hline \multirow{2}{*}{ Dioscorea sylvatica } & CMs & 3 & 12 & 7 & 28 & 3 & 12 & 0 & 0 & 0 & 0 & 13 & 12 \\
\hline & THPs & 1 & 2.5 & 28 & 45 & 24 & 60 & 4 & 10 & 8 & 40 & 65 & 36 \\
\hline \multirow{2}{*}{ Drimia sanguinea } & $\mathrm{CMs}$ & 17 & 68 & 15 & 60 & 21 & 84 & 25 & 100 & 6 & 60 & 84 & 76 \\
\hline & THPs & 37 & 92.5 & 32 & 80 & 35 & 87.5 & 39 & 97.5 & 18 & 90 & 161 & 89 \\
\hline \multirow{2}{*}{$\begin{array}{l}\text { Siphonochilus } \\
\text { aethiopicus }\end{array}$} & CMs & 21 & 84 & 22 & 88 & 24 & 96 & 25 & 100 & 8 & 80 & 100 & 91 \\
\hline & THPs & 40 & 100 & 35 & 87.5 & 35 & 87.5 & 40 & 100 & 18 & 90 & 168 & 93 \\
\hline \multirow{2}{*}{ Warburgia salutaris } & $\mathrm{CMs}$ & 23 & 92 & 19 & 76 & 15 & 60 & 21 & 84 & 5 & 50 & 83 & 75 \\
\hline & THPs & 40 & 100 & 37 & 92.5 & 32 & 80 & 39 & 97.5 & 18 & 90 & 166 & 92 \\
\hline
\end{tabular}

Key: C = Capricorn, $\mathrm{S}=$ Sekhukhune, $\mathrm{M}=$ Mopani, $\mathrm{W}=$ Waterberg, $\mathrm{V}=$ Vhembe, $\mathrm{CMs}=$ Community members, THPs $=$ Traditional health practitioners.

\subsection{Medicinal Applications of Plants}

Alepidea amatymbica and B. zanguebarica were used chiefly by THPs $(63.33 \%, n=114$, $60 \%, n=108$, respectively) for treating parapsychological issues, Only $10 \%$ of CMs $(n=11$ and $20 \%, n=22$, respectively) utilized these two species (Table 3). Drimia sanguinea was the species of choice for the treatment of circulatory problems $(72.78 \%, n=131$ of THPs and $66.36 \%, n=73$ of CMs). Siphonochilus aethiopicus was used by both groups of participants 
mainly for the treatment of digestive, respiratory and parapsychological ailments; while W. salutaris was mainly used for circulatory, immune and respiratory problems (Table 3).

Table 3. The use pattern of the selected TOPS-listed species for each disease category.

\begin{tabular}{|c|c|c|c|c|c|c|c|c|c|c|c|c|c|c|c|c|}
\hline \multirow{2}{*}{ Species } & \multirow{2}{*}{ Participants } & \multicolumn{13}{|c|}{ Disease Categories (Numbers) } & \multicolumn{2}{|c|}{$\begin{array}{c}\text { Total } \\
\text { (Numbers) }\end{array}$} \\
\hline & & $\mathrm{C}$ & De & Di & $\mathrm{E}$ & G & $\mathbf{I}$ & $\mathbf{N}$ & $\mathrm{O}$ & $\mathbf{P}$ & $\mathbf{R p}$ & Rs & $\mathrm{S}$ & Sm & & \\
\hline \multirow{2}{*}{ Alepidea amatymbica } & CMs & 1 & 0 & 2 & 1 & 0 & 0 & 1 & 0 & 11 & 0 & 2 & 0 & 0 & 18 & \multirow{2}{*}{187} \\
\hline & THPs & 2 & 2 & 11 & 0 & 0 & 4 & 4 & 0 & 114 & 5 & 26 & 0 & 1 & 169 & \\
\hline \multirow{2}{*}{$\begin{array}{c}\text { Brackenridgea } \\
\text { zanguebarica }\end{array}$} & CMs & 1 & 0 & 1 & 0 & 0 & 0 & 0 & 0 & 22 & 0 & 0 & 0 & 0 & 24 & \multirow{2}{*}{158} \\
\hline & THPs & 4 & 12 & 5 & 0 & 0 & 1 & 3 & 0 & 108 & 1 & 0 & 0 & 0 & 134 & \\
\hline \multirow{2}{*}{ Dioscorea sylvatica } & CMs & 6 & 1 & 0 & 0 & 0 & 0 & 0 & 0 & 5 & 0 & 0 & 0 & 0 & 12 & \multirow{2}{*}{86} \\
\hline & THPs & 20 & 3 & 3 & 0 & 0 & 6 & 0 & 0 & 42 & 0 & 0 & 0 & 0 & 74 & \\
\hline \multirow{2}{*}{ Drimia sanguinea } & $\mathrm{CMs}$ & 73 & 17 & 4 & 4 & 0 & 13 & 0 & 0 & 10 & 3 & 2 & 11 & 0 & 137 & \multirow{2}{*}{392} \\
\hline & THPs & 131 & 19 & 15 & 3 & 2 & 16 & 3 & 0 & 33 & 10 & 6 & 16 & 1 & 255 & \\
\hline \multirow{2}{*}{$\begin{array}{l}\text { Siphonochilus } \\
\text { aethiopicus }\end{array}$} & $\mathrm{CMs}$ & 1 & 6 & 77 & 1 & 1 & 1 & 1 & 0 & 35 & 1 & 55 & 2 & 0 & 181 & \multirow{2}{*}{466} \\
\hline & THPs & 2 & 14 & 69 & 3 & 0 & 3 & 8 & 0 & 68 & 1 & 115 & 2 & 0 & 285 & \\
\hline \multirow{2}{*}{ Warburgia salutaris } & CMs & 22 & 3 & 3 & 1 & 0 & 14 & 1 & 0 & 5 & 5 & 57 & 3 & 0 & 114 & \multirow{2}{*}{380} \\
\hline & THPs & 67 & 19 & 15 & 2 & 0 & 35 & 3 & 1 & 20 & 5 & 98 & 1 & 0 & 266 & \\
\hline Total & & 330 & 96 & 205 & 15 & 3 & 93 & 24 & 1 & 473 & 31 & 361 & 35 & 2 & & \\
\hline
\end{tabular}

Key: $\mathrm{CMs}=$ Community members, $\mathrm{TH}=$ Traditional health practitioners, $\mathrm{C}=$ Circulatory, De $=$ Dermatology, $\mathrm{Di}=$ Digestive, $\mathrm{E}=$ Endocrine, $\mathrm{G}=$ Genito-urinal, $\mathrm{I}=$ Immune, $\mathrm{N}=$ Nervous, $\mathrm{O}=$ Optical, $\mathrm{P}=$ Parapsychological, $\mathrm{Rp}=$ Reproductive, $\mathrm{Rs}=$ Respiratory, $\mathrm{S}=$ Sexually Transmitted Diseases, $\mathrm{Sm}=$ Skeletomuscular.

In each disease category (Table 3), one species was often used to treat a variety of ailments. However, only the four most treated disease categories are shown below, with, the three most treated ailments from each of these categories, and the three most used species indictated.

\subsubsection{Circulatory Problems}

In terms of specific ailments, body pains were most often treated, followed by high blood pressure and swollen legs. The mentioned ailments were treated mostly using D. sylvatica, D. sanguinea and W. salutaris.

It was found that across all districts (except the Vhembe District), D. sylvatica was the species most commonly used to treat swollen legs by both THPs and CMs (Figure 2). THPs and CMs in Sekhukhune District reported its use for treating body pains. THPs in Sekhukhune and Mopani districts also used this species to control high blood pressure by (Figure 2).

Drimia sanguinea was widely used by both survey groups in all districts to treat body pains. In the Vhembe District, the only circulatory ailment treated using this species was body pains. This species was also used to treat high blood pressure; this use was reported by both groups of participants in Sekhukhune, Mopani, Waterberg districts, but only by $\mathrm{CMs}$ in the Capricorn District. The use of this species to treat swollen legs was mainly reported by THPs (Figure 2).

Both informant groups utilized Warburgia salutaris to treat body pains. This was true across all districts, except in the Vhembe district where the knowledge of $W$. salutaris as medicine for this ailment was restricted to THPs only. THPs in the Capricorn District and CMs in the Mopani and Waterberg districts also used this species to control high blood pressure (Figure 2). 


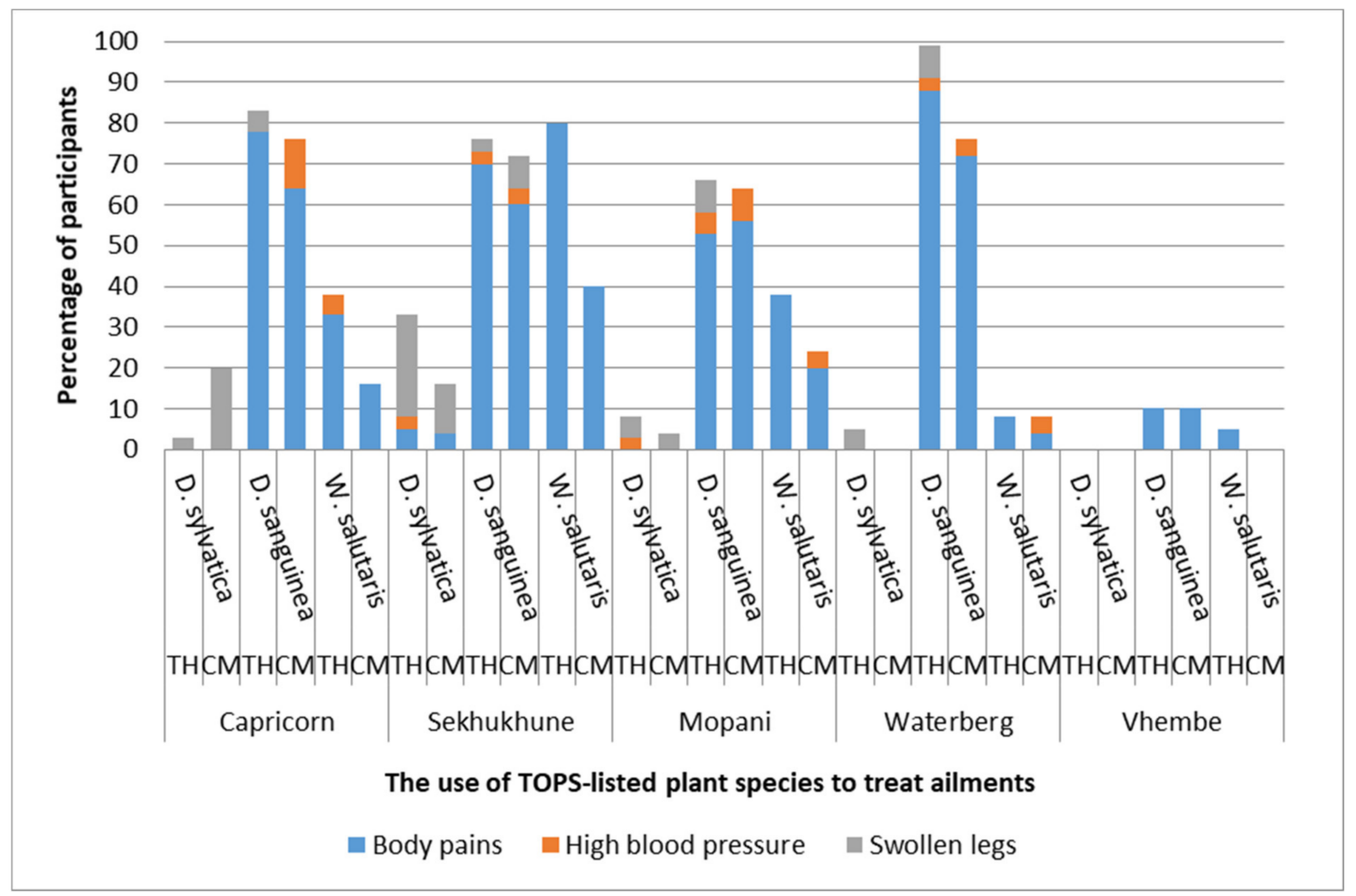

Figure 2. Treatment of circulatory problems in the five districts of the Limpopo Province.

\subsubsection{Digestive Problems}

The most commonly treated digestive ailments were constipation after attending funerals, stomach pains in infants and stomach ache/disorders. Species such as D. sanguinea, S. aethiopicus and $W$. salutaris were the species most used for these mentioned ailments. Drimia sanguinea was only used to treat stomach ache/disorders in this ailment category. It was used by CMs in the Capricorn and Waterberg districts, and also by THPs in the Sekhukhune district (Figure 3). The medicinal plant most commonly used by CMs and THPs to treat digestive problems was S. aethiopicus. As to stomach pain in infants, this species was chiefly used by THPs in all districts, while a minor use is made by CMs in all districts, except in the Sekhukhune District. It was commonly used as a medicine for constipation only after attending a funeral. This was mainly reported by CMs, and to a lesser extent by THPs, in all districts, except Sekhukhune (Figure 3). Warburgia salutaris was used mostly by THPs to treat digestive problems, chiefly stomach ache, in the Mopani and Vhembe districts, and only for treating constipation after attending a funeral in the Waterberg District (Figure 3).

\subsubsection{Respiratory Problems}

The most treated ailments in this category include coughs, sore throats and breathing difficulties in infants. These ailments were mostly treated using A. amatymbica, S. aethiopicus and W. salutaris. Alepidea amatymbica was commonly used by THPs to treat coughing symptoms in the Capricorn, Sekhukhune and Waterberg districts (Figure 4). Siphonochilus aethiopicus were generally used by THPs and CMs to treat coughs in the Capricorn, Sekhukhune, Mopani and Waterberg districts (Figure 4). This species was only used by THPs in the Capricorn and Waterberg districts and by CMs in the Sekhukhune and Mopani districts to treat breathing difficulties in infants. Furthermore, it was used to treat sore throats in all districts, except Vhembe, predominantly by CMs. Warburgia salutaris was used by 
THPs and CMs across all districts, to treat respiratory problems. THPsand CMs in the Sekhukhune District used this species to treat the two most mentioned ailments (coughs and sore throats). In the Vhembe District, it was only used to treat coughs (Figure 4).

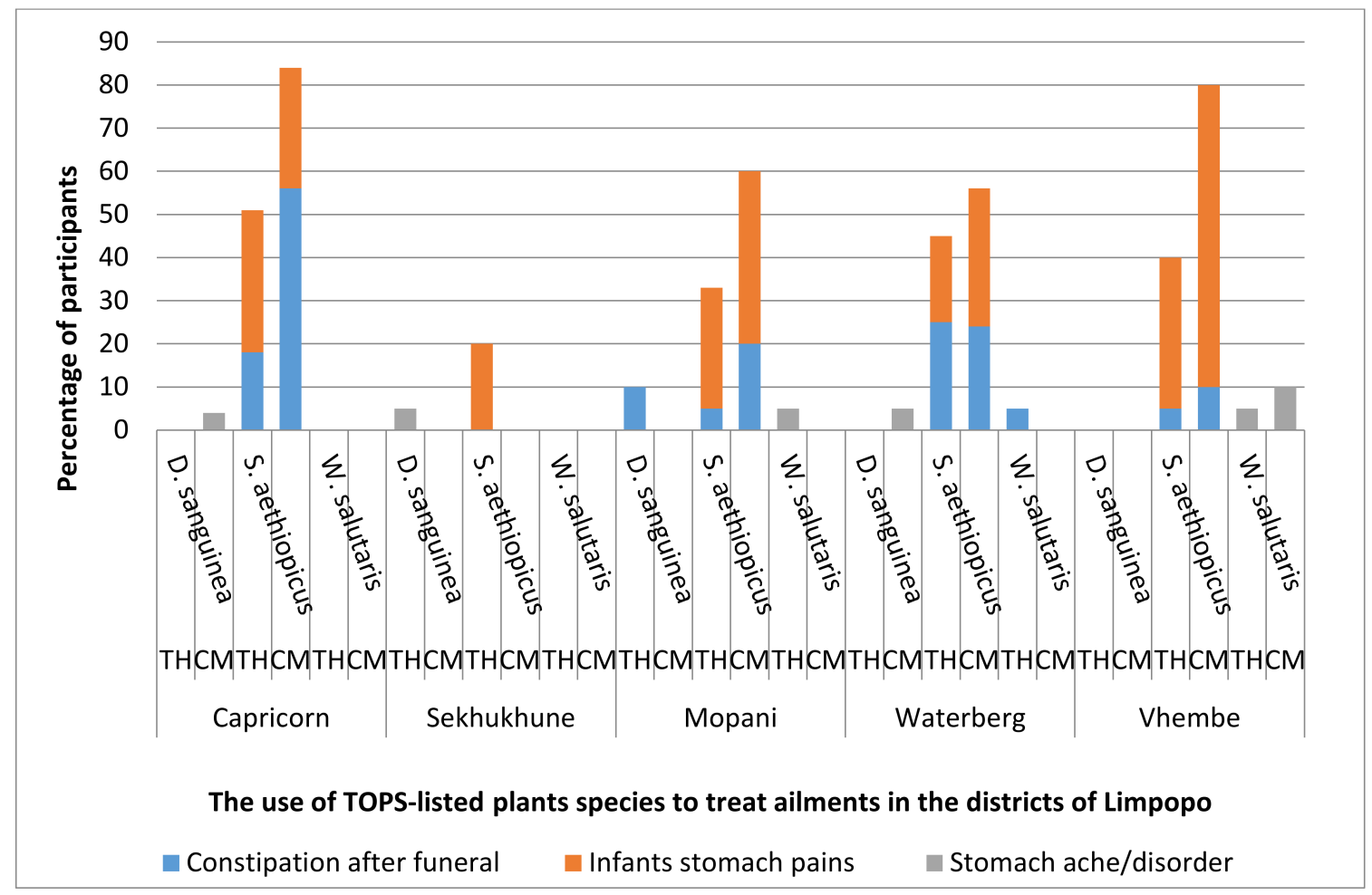

Figure 3. Treatment of digestive problems in the five districts of the Limpopo Province.

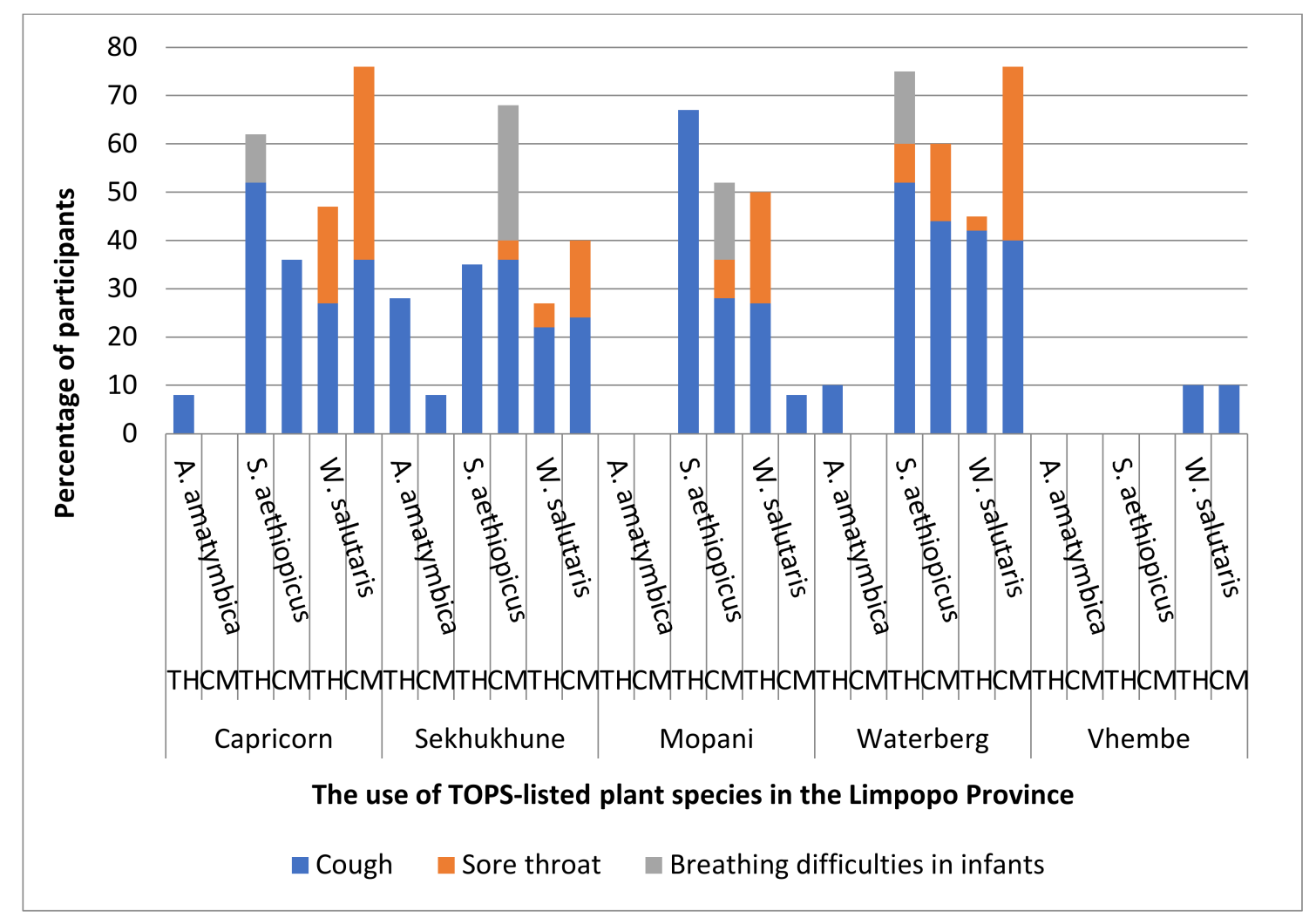

Figure 4. Treatment of respiratory problems in the five districts of the Limpopo Province. 


\subsubsection{Parapsychological Problems}

Parapsychological is a category associated with beliefs or myths. The most used beliefs and myths include: Protecting homesteads, catalysts for the healing process of any disease, and good luck. The plants species most used to treat these problems were $B$. zanguebarica, S. aethiopicus and A. amatymbica. THPs were found to be the practitioners most commonly utilizing these plant species for parapsychological purposes, with very few CMs prescribing these species for such purposes. Brackenridgea zanguebarica was mostly used by THPs to protect homesteads (Figure 5). Only THPs in the Mopani district used this species as a catalyst to treat any disease. In all districts of the province, THPs and CMs prescribed this species for bringing good luck. Siphonochilus aethiopicus was the species used the least for parapsychological purposes. However, this species was used as a catalyst for the healing process of any disease, and also good luck (Figure 5). Alepidea amatymbica was used mostly by THPs for protecting homesteads and for bringing luck (except in the Mopani and Vhembe districts). In Waterberg and Sekhukhune districts some CMs and THPs also used this species as a catalyst for any disease (Figure 5).

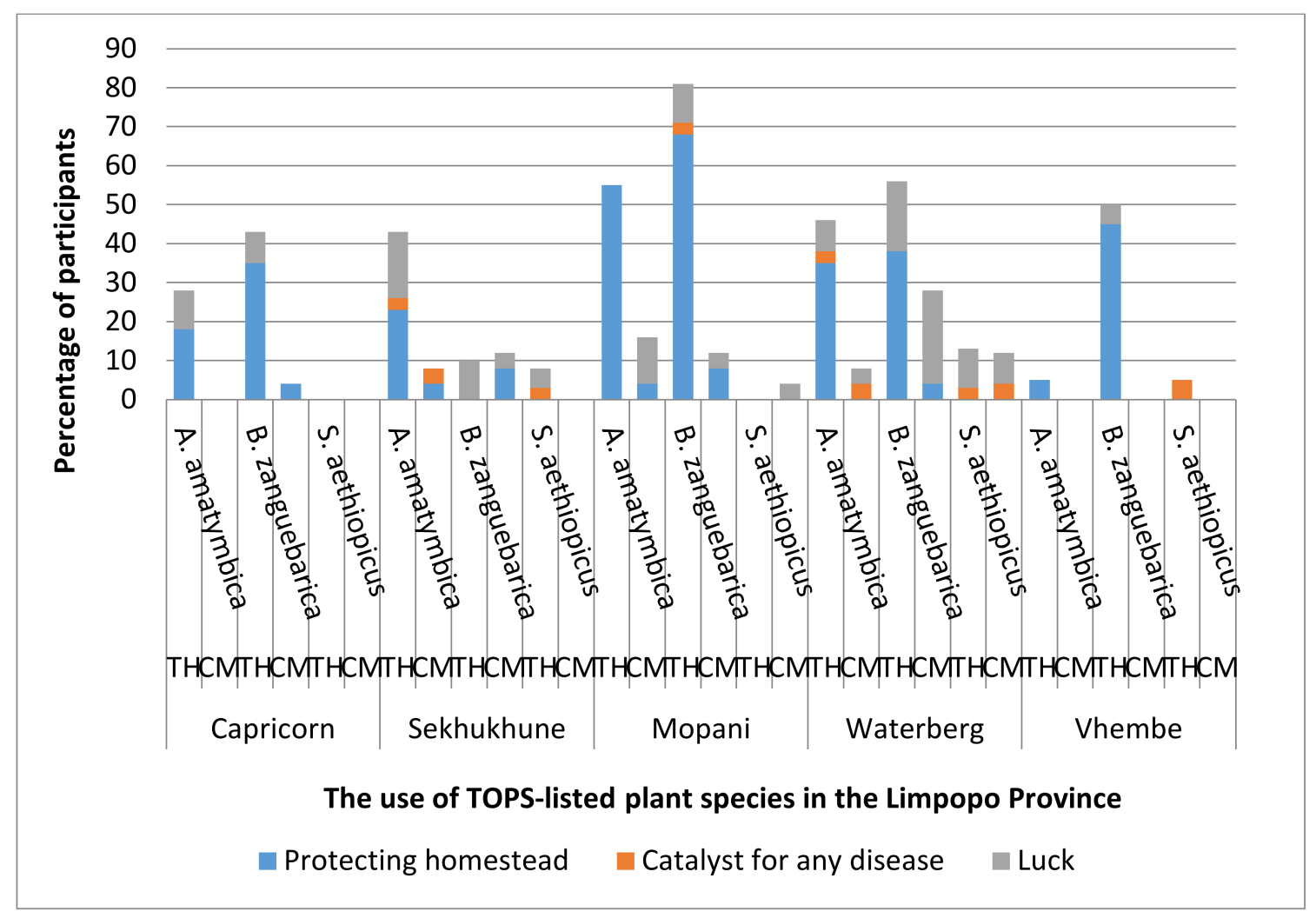

Figure 5. Use of study species for parapsychological purposes in the five districts of the Limpopo Province.

\subsection{Herbal Remedies \\ 3.3.1. Parts Used}

Results indicate that underground parts of all six plant species were being harvested. The study noted that THPs refill hole after harvesting underground parts of the TOPS listed plants, they believed this practice promotes regrowth of the harvested plant. Brackenridgea zanguebarica (roots and bark) and W. salutaris (bark and leaves) were also being targeted for other parts. The harvesting of the bark was solely from the sun facing side, reasoned that the eastern side had more healing contents compared to all other sides.

It was also noted that most of the parts were dried first before preparing the material for use (Table 4). All THPs mentioned that the dry state of the plant is preferred because 
it extends shelf life, as compared to fresh or liquid state. Dry plant parts can survive for longer periods even when exposed to hotter climates.

Table 4. Parts and form of parts used in the six selected TOPS-listed plant species.

\begin{tabular}{ccc}
\hline Plant Species & Parts Used & State of Plant Parts \\
\hline Alepidea amatymbica & Roots $(100 \%)$ & Dry \\
\hline Brackenridgea zanguebarica & Roots $(97 \%)$ and bark $(3 \%)$ & Dry \\
\hline Dioscorea sylvatica & Tuber $(100 \%)$ & Dry \\
\hline Drimia sanguinea & Bulb $(100 \%)$ & Fresh \\
\hline Siphonochilus aethiopicus & Rhizome $(100 \%)$ & Fresh \\
\hline Warburgia salutaris & Bark $(94 \%)$, roots $(4 \%)$ and & Dry \\
\hline
\end{tabular}

\subsubsection{Method of Preparation}

Five different methods of preparation were identified, which include: (a) The preparation of extracts (in the form of cooking or boiling), (b) burning (dried plant material is burnt or put on charcoal and smoke inhaled), (c) powdering (cut into small pieces, dried and then crushed to fine powder), (d) infusion (soaked in water for long hours), and (e) leaving the material in its raw state. Fifty four point nineteen percent of respondents used the extract method of preparing their decoctions. Twenty-five percent of interviewees used their plants in a raw state, and $16.44 \%$ used it as powder. However, the preparation differed between the studied species (Figure 6).

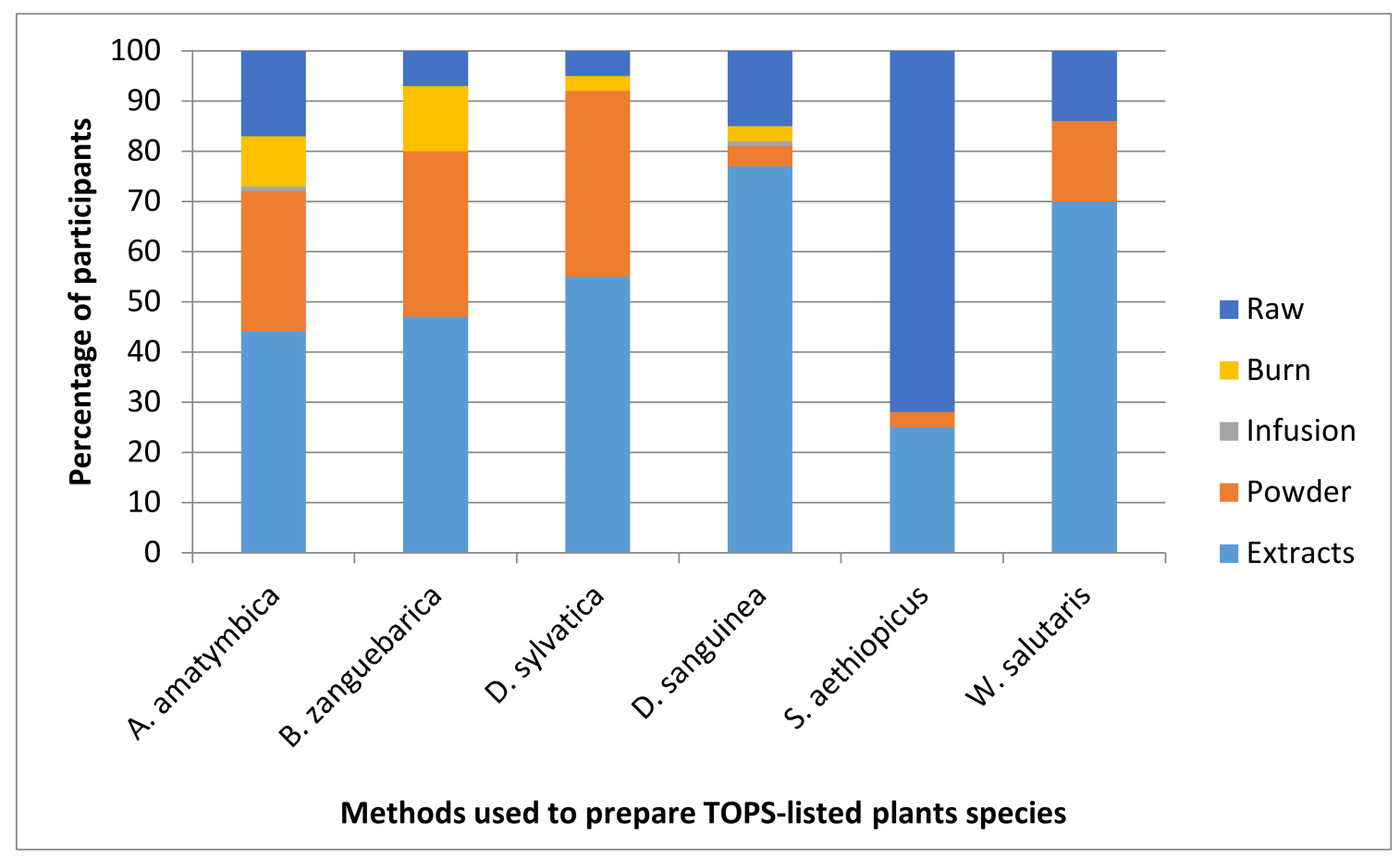

Figure 6. Different methods of preparation in the studied TOPS-listed plant species.

Siphonochilus aethiopicus was the only species mostly used in a raw state; all the other species were used mostly as extracts decoctions, and to a lesser extent as powder (Figure 6). Only A. amatymbica, B. zanguebarica and D. sanguinea were reported to be burnt, sometimes before administration. Infusion as a method of preparation was only reported for A. amatymbica and D. sanguinea (Figure 6). 


\subsubsection{Mode of Administration}

Six different modes of herbal administration were documented: Oral, topical, inhalation, enema, embedded and blow/sprinkled. These modes are closely linked to the methods of preparation. For example, extracts can be administered orally, topically, via enema or blown/sprinkled. The powder can be blown/sprinkled or taken orally and an infusion can be administered via oral or sprinkling. A remedy that is in a raw state can be administered either orally, topically or be blown/sprinkled. Burning can only be administered by inhalation of smoke.

The oral method of administration was mostly in the form of drinking water, milk, beer, eating soft porridge, teeth rubbing, chewing or sublingual. Topical methods included lotions, bathing, massage or incision, while sprinkling involved scattering in yards and graveyards, or blowing in the direction of a recipient or all directions. Enema involved anally administrating the remedy using a bulb syringe, while embedded (mainly used for parapsychological uses) involved placing the material in coat pockets, shoes, in traditional bones, attaching it under vehicles, planting the stated plant at corners of the yard or gate. Others included preparing the material as ties and necklaces for children, applying it on doors, windows and doorsteps, as well as polishing the floor with the plant material.

The most used modes of administration found in the study were oral and topical (Figure 6). The species administered predominantly orally, were W. salutaris, D. sanguinea and S. aethiopicus. Brackenridgea zanguebarica and D. sylvatica were less commonly administered orally. The only species that were not administered by inhalation were $W$. salutaris and D. sylvatica. Drimia sanguinea was not blown/sprinkled around as a method of administration. Even though S. aethiopicus was not prepared by burning (Figure 6), it can be administered through inhalation, sometimes referred to as aromatherapy (Figure 7).

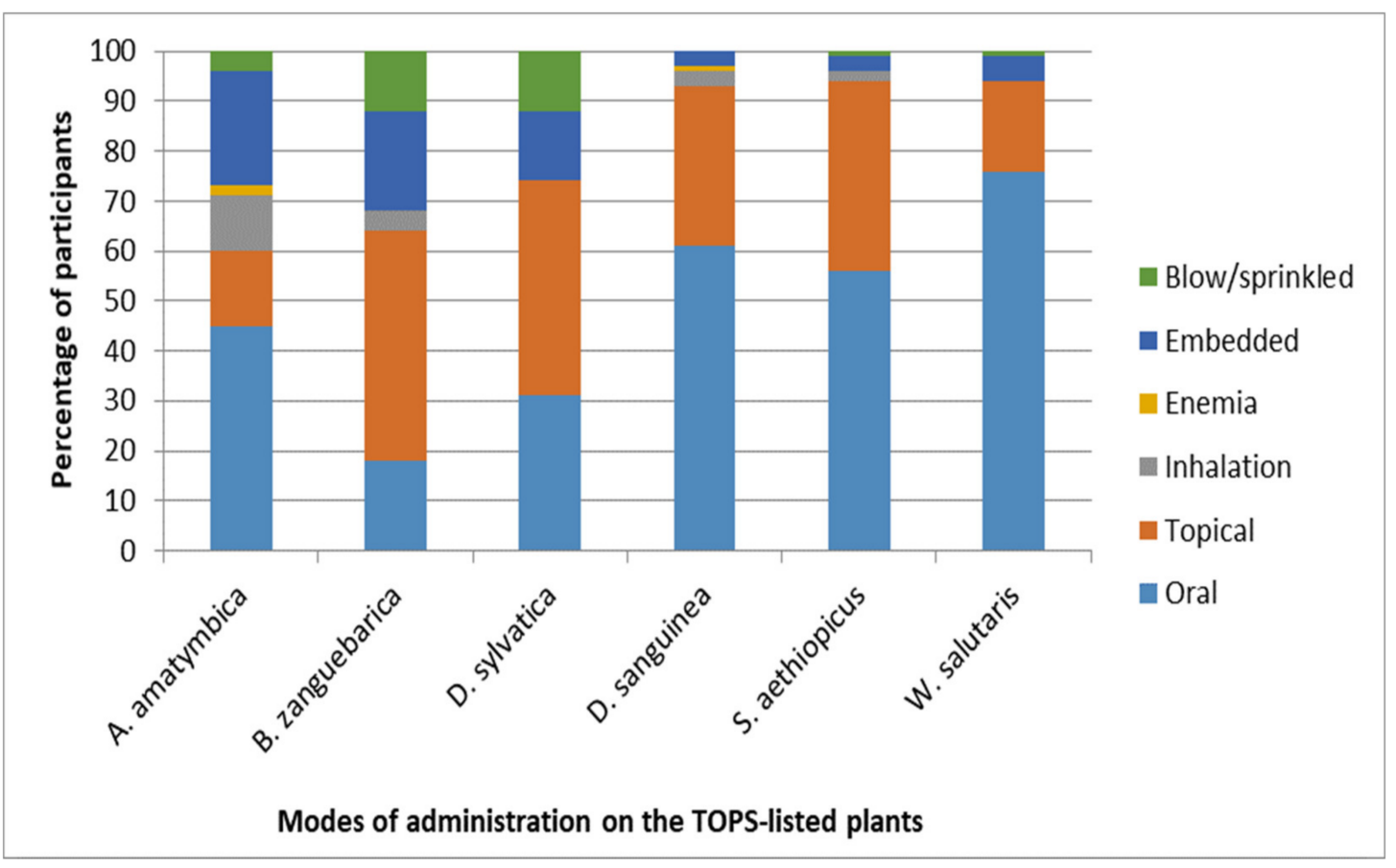

Figure 7. Different modes of administration of the studied TOPS-listed plant species.

\subsection{Plant Collection}

\subsubsection{Source}

It was noted that $59.01 \%$ of participants sourced their plants from muthi traders and $39.50 \%$ from the wild. A minority $(1.49 \%)$ sourced material from their home gardens. It must be noted that the source varied slightly according to the species used and the users in the different districts (Table 5). 
Table 5. Source of TOPS-listed plant species used by traditional health practitioners and community members in the five districts of the Limpopo Province.

\begin{tabular}{|c|c|c|c|c|c|c|c|c|c|c|c|c|c|c|c|c|}
\hline \multirow{3}{*}{ Plant Species } & \multirow{3}{*}{ Participants } & \multicolumn{3}{|c|}{$\begin{array}{c}\text { Capricorn } \\
\text { District }\end{array}$} & \multicolumn{3}{|c|}{$\begin{array}{c}\text { Sekhukhune } \\
\text { District }\end{array}$} & \multicolumn{3}{|c|}{$\begin{array}{l}\text { Mopani } \\
\text { District }\end{array}$} & \multicolumn{3}{|c|}{$\begin{array}{c}\text { Waterberg } \\
\text { District }\end{array}$} & \multicolumn{3}{|c|}{$\begin{array}{l}\text { Vhembe } \\
\text { District }\end{array}$} \\
\hline & & \multicolumn{15}{|c|}{ Source of Plant (\% of Participants) } \\
\hline & & $\mathbf{W}$ & $\mathbf{H}$ & B & $\mathbf{W}$ & $\mathbf{H}$ & B & $\mathbf{W}$ & $\mathbf{H}$ & B & $\mathbf{W}$ & $\mathbf{H}$ & B & $\mathbf{W}$ & $\mathbf{H}$ & B \\
\hline \multirow{2}{*}{ Alepidea amatymbica } & THPs & 30 & 0 & 70 & 41 & 3 & 59 & 29 & 3 & 68 & 18 & 0 & 82 & 0 & 0 & 100 \\
\hline & CMs & 0 & 0 & 0 & 0 & 0 & 100 & 71 & 0 & 29 & 0 & 0 & 100 & 0 & 0 & 0 \\
\hline \multirow{2}{*}{$\begin{array}{l}\text { Brackenridgea } \\
\text { zanguebarica }\end{array}$} & THPs & 32 & 0 & 68 & 23 & 0 & 77 & 19 & 0 & 81 & 14 & 0 & 86 & 25 & 0 & 75 \\
\hline & $\mathrm{CMs}$ & 0 & 0 & 0 & 0 & 0 & 100 & 0 & 0 & 100 & 0 & 0 & 100 & 0 & 0 & 0 \\
\hline \multirow{2}{*}{$\begin{array}{c}\text { Dioscorea } \\
\text { sylvatica }\end{array}$} & THPs & 100 & 0 & 0 & 86 & 0 & 14 & 67 & 0 & 33 & 25 & 0 & 75 & 0 & 0 & 100 \\
\hline & $\mathrm{CMs}$ & 100 & 0 & 0 & 100 & 0 & 0 & 0 & 0 & 100 & 0 & 0 & 0 & 0 & 0 & 0 \\
\hline \multirow{2}{*}{$\begin{array}{c}\text { Drimia } \\
\text { sanguinea }\end{array}$} & THPs & 73 & 16 & 11 & 81 & 0 & 19 & 77 & 0 & 23 & 41 & 3 & 56 & 44 & 0 & 56 \\
\hline & CMs & 59 & 12 & 29 & 80 & 0 & 20 & 62 & 0 & 38 & 40 & 0 & 60 & 0 & 0 & 100 \\
\hline \multirow{2}{*}{$\begin{array}{l}\text { Siphonochilus } \\
\text { aethiopicus }\end{array}$} & THPs & 8 & 5 & 88 & 20 & 3 & 77 & 49 & 0 & 51 & 20 & 3 & 78 & 11 & 17 & 72 \\
\hline & CMs & 13 & 0 & 87 & 0 & 0 & 100 & 29 & 0 & 71 & 0 & 0 & 100 & 0 & 0 & 100 \\
\hline \multirow{2}{*}{$\begin{array}{l}\text { Warburgia } \\
\text { salutaris }\end{array}$} & THPs & 75 & 0 & 25 & 76 & 0 & 24 & 38 & 0 & 63 & 18 & 0 & 82 & 33 & 0 & 67 \\
\hline & CMs & 61 & 0 & 58 & 58 & 0 & 42 & 20 & 0 & 80 & 10 & 0 & 90 & 0 & 0 & 100 \\
\hline
\end{tabular}

Key: (W) Wild, (H) Homegarden and (B) Buy.

Alepidea amatymbica was sourced mainly by THPs and CMs from muthi shops. Only, THPs from the Sekhukhune and Mopani districts collected this species from their home gardens. This species was also obtained from wild communal areas in all the districts, except in the Vhembe District. Through field observations it was found that this species occurs in a few communal areas in the Mopani district, and the Lydenberg area in Mpumalanga.

Brackenridgea zanguebarica was also chiefly sourced from muthi shops. None of the participants cultivated the species in their home garden. THPs from all districts also sourced this plant from the wild. A natural population of this species was also observed in the Vhembe District, in a nature reserve.

Both CMs and THPs generally sourced Dioscorea sylvatica from the wild (communal areas) in the Capricorn District. Wild population harvesting was very high in the Sekhukhune District and amongst THPs in the Mopani and Waterberg districts. Field observations revealed that only two natural populations of this species occur in the Sekhukhune district: the Leolo and Ga-Phaahla Mountains.

Drimia sanguinea was largely sourced from the wild, though in the Waterberg and Vhembe districts muthi shops featured more as a source. This species was only cultivated in home gardens by a minority of THPs and CMs in the Capricorn District and to a much lesser degree by THPs in the Waterberg district. This species occurred in several communal areas across the Capricorn, Sekhukhune and Mopani districts.

Siphonochilus aethiopicus was cultivated to a limited degree by THPs in their home gardens (3-7\% of THPs), except for those in the Mopani district, where the species is still to a very limited extent available from communal areas. With the exception of the Mopani District, this species was more commonly bought from muthi shops than collected from the wild.

Warburgia salutaris was either sourced from muthi shops or from the wild. Participants in the Capricorn and Sekhukhune districts mostly sourced this species from the wild, while participants in other districts generally obtained material from muthi shops. Several populations of this species were observed in the Capricorn and Sekhukhune districts. In the Capricorn district, it was collected from numerous mountains in the Blouberg and Mafefe areas. 


\subsubsection{Perception on Local Availability}

Even though most of the participants collected certain species from the same areas, they had different perceptions regarding the availability of these plants in the wild. Most species are perceived to be on the decline while others are considered fairly abundant in the wild (Figure 8). According to those participants who harvested the species in the wild, A. amatymbica, B. zanguebarica and W. salutaris populations are mostly declining (Figure 8). This dichotomy in perception also extended to D. sylvatica and D. sanguinea, where some perceived them to be common in the wild, while others noted that these species are declining, and becoming rare and thus very difficult to find. Most collectors (76\%) of $S$. aethiopicus indicated that the species is either rare or declining in the wild, while a minority $24 \%$ indicated that the species is still common (Figure 8 ).

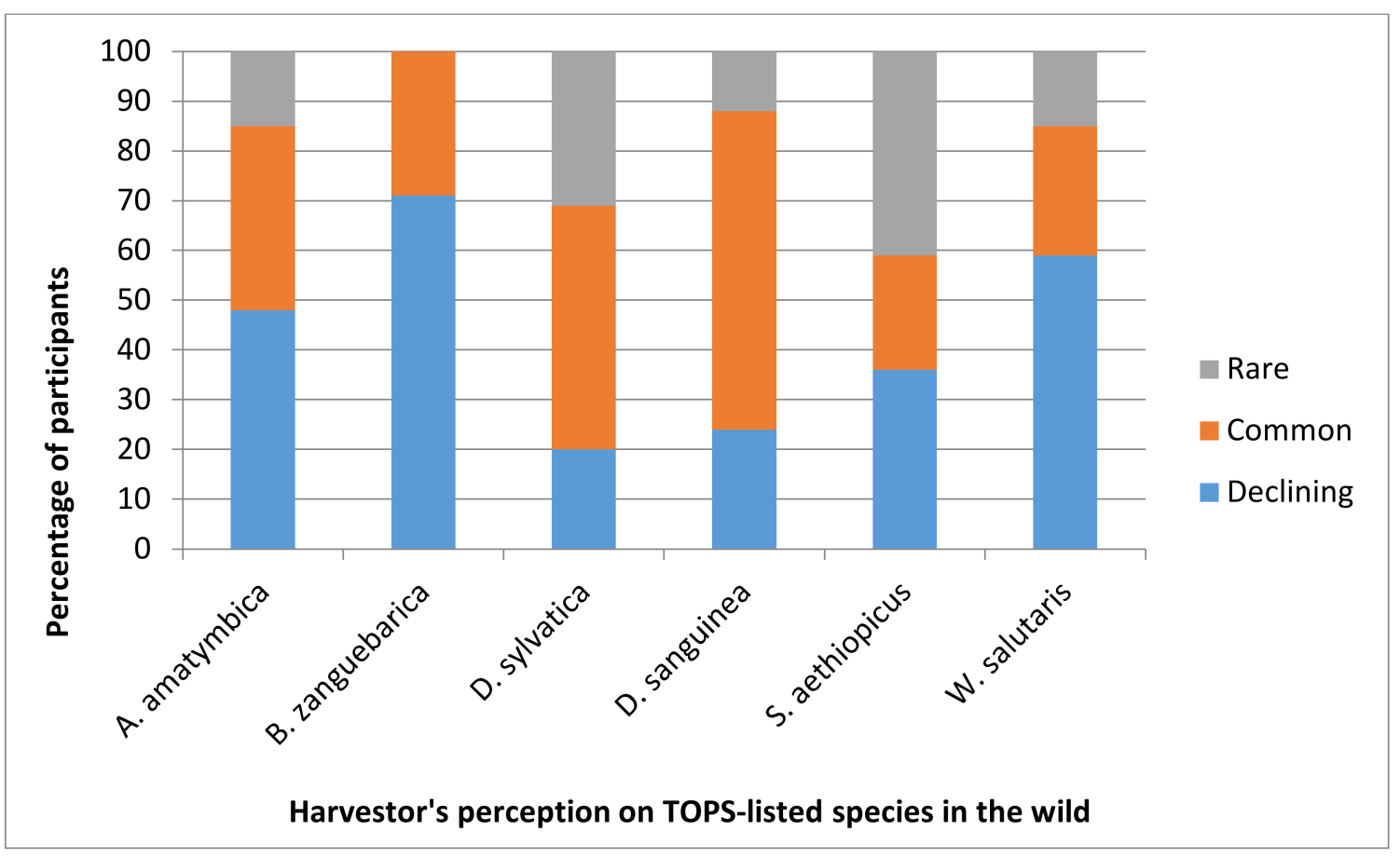

Figure 8. Perception of harvesters of TOPS-listed plants on their availability in the wild.

\section{Discussion}

\subsection{Species Utilization}

The current study is the first to comprehensively focus specifically on the use of TOPS-listed plant species (i.e., species protected and regulated by national legislation), particularly to THPs and CMs, in the Limpopo Province and South Africa at large. It is, however, important to point out that several general studies conducted across South Africa repeatedly highlighted the utilization of some of the selected species.

The investigated species were used as medicine in all five districts of the Limpopo Province. Generally, THPs used these species more than CMs. This was to be expected as THPs are known [19-21] to be the main custodians of indigenous knowledge as far as herbal medicine are concerned. In addition, the interest of CMs towards the use of such species in home remedies is rapidly fading, as most are influenced by the adoption of western practices the promotion of modern medical facilities (clinics and hospitals) by government, as well as religions like Christianity, which strongly prohibit self-medication [22]. Subsequently, most CMs, when approached for an interview, mentioned that they could not even remember the medicinal applications of a single species. The low number of CMs working with medical plants is, however, concerning as it is indicative of an erosion of cultural knowledge by members of various cultural tribes in the Limpopo Province. 
This loss of cultural knowledge will have long term negative consequences for African Traditional medicine practices.

Of the six investigated species, S. aethiopicus, W. salutaris and D. sanguinea were the ones most used by THPs and CMs. The popularity of these species in traditional medicine is in line with other cultures in the Limpopo Province $[10,19,20]$ and the rest of South Africa [5,16]. Indeed, Maroyi [23] noted that insight into the societal value of Warburgia species in southern Africa can be gained by examining these vernacular names. People rarely name plant species that they do not use. Thus the vernacular names ishibaha, isibaha, manaka, and mulanga used by the VhaVenda is indicative of a very close cultural association. The cultural acceptance of these three species stem from their wide applications in effectively treating a number of ailments (see Section 4.2 below) with no side effects for many decades or centuries. Thus, these species have been culturally validated by several ethnic groups.

The species which were least used by both CMs and THPs were B. zanguebarica and $D$. sylvatica. None of the interviewed CMs from Capricorn or Vhembe districts selfmedicate with B. zanguebarica. This is normal behaviour as the harvest of this tree is associated with completed ritual performances known only by people from the clan and THPs [20] and therefore, ordinary CMs are not expected to have it or use it. The limited use of $B$. zanguebarica by THPs might be because the species generally only occurs in a protected area, and falls under strictly enforced permit regulations, which add to its inaccessibility. Similarly, none of the interviewed CMs residing in the Waterberg and Vhembe districts used D. sylvatica. This might be due to its limited distribution in these districts or lack of knowledge regarding its medicinal applications amongst participants, which again points to a decline in cultural knowledge within and among tribes.

\subsection{Medicinal Applications of Plants}

\subsubsection{Circulatory Problems}

The three most treated ailments were body pains, swollen legs and high blood pressure. The three most used species to treat ailments in these categories were D. sylvatica, $D$. sanguinea and $W$. salutaris. In all districts, D. sylvatica was used to treat swollen legs. Studies conducted in the provinces of Limpopo [24] and Free State [25] in South Africa, concur with this finding. This species was also used by THPs in the Sekhukhune and Mopani districts of the Limpopo Province to treat high blood pressure. No medicinal applications record of D. sylvatica for high blood pressure was found in the literature, and this reported use is thus a first. However, its utilisation in the treatment of body pains was also reported by Philander [26] for the Rastafarians in the Western Cape Province, by Kelmanson et al. [27] for the Zulus in KwaZulu-Natal, and by Cogne et al. [28] for the Shona in Zimbabwe. The application of this species as a pain reliever thus needs further investigation regarding its bioactivity.

Drimia sanguinea was widely used in all districts to treat body pains. The extensive use of this species was also noted by Mongalo [5] for the Blouberg area of the Limpopo Province. Motlhanka and Nthoiwa [29] also documented its use by the indigenous tribes of Botswana. The medicinal use of $D$. sanguinea as a blood pressure regulator was also documented by Rankoana [30]. To the best of our knowledge, the use of this species to treat swollen legs by our study is a first record.

The use of $W$. salutaris for the treatment of body pains was widely mentioned by both groups of participants in all districts, except the Vhembe District, where only THPs mentioned this use, a phenomenon that must be further investigated. This treatment is supported by Rankoana [30], who documented its use for the treatment of pains on joints. Furthermore, this species was also used to treat high blood pressure. Its use to treat high blood is a first record for South Africa. The above-mentioned uses are, however, also common in other African countries such as Kenya [31], Zimbabwe [23] and Mozambique [32]. 


\subsubsection{Digestive Problems}

Constipation after attending funerals, stomach pains in infants and stomach ache/ disorder were the most treated digestive ailments, using D. sanguinea, S. aethiopicus and W. salutaris. Drimia sanguinea was used for treating stomach disorders, which was also reported by Marx et al. [33]. None of the recorded uses of S. aethiopicus in this study for digestive purposes were previously recorded in the literature. A few of the recorded uses of $W$. salutaris in this study were also documented in other countries. For instance, its use in the treatment of constipation after attending funerals as reported by THPs in the Waterberg district was also documented by Phanuel et al. [34] in Kenya. Furthermore, its use to treat stomach ache/disorders is consistent with the findings of Senkoro et al. [32] in Mozambique.

\subsubsection{Respiratory Problems}

Overall, coughs, sore throats and TB (Tuberculosis) were the most treated respiratory ailments with A. amatymbica, S. aethiopicus and W. salutaris. The uses of these species to treat coughs are common in South Africa and other African countries. For example, the use of A. amatymbica for coughs was also mentioned by Omoruyi et al. [35] and Semenya and Maroyi [36] in South Africa and Maroyi [37] in Zimbabwe. The medicinal use of S. aethiopicus and W. salutaris for coughs is also reported in South Africa $[24,36]$ and Zimbabwe [23]. The effectiveness of some of these species against coughs is supported by $[24,38]$ for $A$. amatymbica and $[23,30]$ for $W$. salutaris. Amongst the species used to treat sore throats, only W. salutaris was previously mentioned for South Africa [36] and Mozambique [32], thus the documentation of A. amatymbica to treat sore throats is a first. Furthermore, amongst species used for TB, only S. aethiopicus [36] and W. salutaris [30] were mentioned in the literature.

\subsubsection{Parapsychological Problems}

Concerning parapsychological issues, B. zanguebarica, S. aethiopicus and A. amatymbica were used primarily for the following beliefs and myths: Protecting homesteads from evil, as a catalyst for the healing process of any disease/ailment, and for bringing luck. The use of $B$. zanguebarica for the protection of homesteads was also mentioned by Tshisikhawe et al. [20] and Magwede et al. [21]. A study by Rasethe et al. [24] alluded to the use of this species for luck and its use as a catalyst for any disease correspond to those reported by Semenya and Mokgoebo [39]. The use of S. aethiopicus as a catalyst was previously mentioned in the literature [30], but no record of its use for luck and the protection of homesteads was previously mentioned in the literature. The use of A. amatymbica to protect homesteads was previously mentioned by Stoffersen et al. [40]. However, its uses as a catalyst for treating any disease and for luck were recorded in this study for the first time. Most of the medicinal use of the investigated species to treat specific problems associated with parapsychological issues have never before been reported in the literature. This shows that medicinal applications of TOPS-listed species are in general poorly recorded in Limpopo Province and South Africa at large. It also indicates that such species are faced with extensive harvesting pressure for multiple medicinal applications.

\subsection{Herbal Remedies}

\subsubsection{Parts Used}

A variety of plant parts from the six studied plants were used for herbal preparation. The underground parts (roots, bulbs and rhizomes) were the most used from Alepidea amatymbica, D. sylvatica, D. sanguinea and S. aethiopicus. This selective practice of harvesting the underground parts of TOPS-listed species was also reported by other researchers in South Africa and other African countries. For example, Moeng [19] noted the collection of $A$. amatymbica and D. sanguinea for medicinal uses in the Limpopo Province. Mathibela [11] found that the bulb of S. aethiopicus was mostly uprooted for medicinal use in the Blouberg area. 
This preference for underground parts is common in South Africa and other African countries [25,41,42]. The high use of underground parts in traditional medicine is mostly based on the cultural perception that they hold the most healing properties of all parts, seeing that they are nearest to the source of the minerals [9]. Thus it is not strange to find that the cultural practice of using the underground parts of plants being consistently reported in different studies $[8,43,44]$ as being highly destructive. Therefore, it is important to find alternative parts to use for traditional uses of the TOPS-listed species in this study. The method of refilling hole with soil after harvesting the underground parts is contrary to findings of Semenya and Potgieter [45] who noted that THPs did not re-fill the soil, because they believe it will worsen a patient's illness. The custom of refilling the hole with soil after harvesting underground parts promotes growth and add value to plant conservation.

Brackenridgea zanguebarica and W. salutaris were the only species harvested for all their various parts. Brackenridgea zanguebarica was mostly harvested for its roots (97\%), but also for bark (3\%). This finding is contrary to that reported by Tshisikhawe et al. [20] in the Vhembe district, who found that bark from the stems of B. zanguebarica was preferred over the roots. The phenomenon of bark harvesting from the sun facing side noted in this study is in line with Magwede [21] in the Limpopo province, it is a cultural belief of the VhaVenda that east-facing bark of trees contain the most healing properties because the western wind is the one bring the healing power. Concerning W. salutaris, in the present study, mainly its bark (94\%) was used by participants as opposed to its roots $(4 \%)$ and leaves $(2 \%)$. Multi-part harvesting of this species with a distinct preference for bark is common in South Africa [11,20] and a similar finding was noted by Senkoro et al. [32] in Mozambique. High bark usage was attributed by different researchers to the higher levels of healing ingredients in bark compared to those contained in other plant parts.

Most of the harvested parts of the investigated plant species were used to prepare medicine in a dry state to increase shelf life excluding D. sanguinea and S. aethiopicus, which were used in a fresh state. The state of use of D. sanguinea and S. aethiopicus can be an indication that users have these species in their home gardens for emergency purposes. On the other hand, species used in dry form shows that users have to travel far distances either for collection or to buy material, and consequently preserve the material in a dry state [19].

\subsubsection{Methods of Herbal Preparations}

Five different methods of herbal preparation were reported for the investigated plants in this study, namely: Extracts (prepared with water in the form of cooking or boiling), powder (cut into small pieces, dried and then crushed to a fine powder), infusion (soaked in water for long hours), raw and burning. These are common methods used for the preparation of herbal medicine from any plant, including some of the TOPS-listed species investigated in this study such as A. amatymbica [45], B. zanguebarica [20], D. sylvatica [38], D. sanguinea [19], S. aethiopicus [19] and W. salutaris [23].

In this study, extracts (54.19\%), raw preparation (25\%) and powdering $(16.44 \%)$ were the most commonly used methods, in contrast to burning (4.03\%) and infusion $(0.34 \%)$. This is probably due to their simplicity of preparation. For example, an infusion usually requires overnight preparation [10], while burning requires constant monitoring to ensure that materials are not completely burned to ash. However, not all of the above mentioned methods of herbal preparation applied to all six investigated species. Drimia sanguinea was the only species prepared using all five recorded methods (burning, extracts, infusion, powder and raw). This may be due to different indigenous knowledge on methods used amongst the participants in the current study. With the exclusion of W. salutaris, which was prepared as extracts, powder and raw, the remaining species were prepared using all the methods recorded in this study except for burning.

\subsubsection{Mode of Administration}

Six different modes of herbal administration were mentioned by participants, with the predominant modes being oral (53.37\%), topical (30.47\%) and embedded $(9.09 \%)$. 
These are all common methods of herbal administration. In the present study, extracts, infusions, powder and raw preparation were taken through oral, topical, embedment, enema or sprinkling. Oral administration was mostly in the form of drinking (via water, milk, beer and soft porridge), rubbing teeth, chewing or sublingual methods. Substances such as milk, beer and soft porridge were used due to the belief that they increase the effectiveness of the medicine. This is a common belief amongst indigenous people in Limpopo Province [10] and other provinces of South Africa, such KwaZulu-Natal [27] and the Eastern Cape Province [35]. Topical administration was in the form of lotion, bathing, massage or incision. These were preparations mostly made from B. zanguebarica and D. sylvatica. Topical administration of medicine prepared from B. zanguebarica was previously mentioned by Tshisikhawe et al. [20] in the Vhembe District. Raw or powdered materials, mainly from A. amatymbica, D. sylvatica and B. zanguebarica was embedded in different ways, by placing in pockets, shoes, in traditional bones, tied under the car, planted at corners of the yard or gate. Others included necklaces for children, applying on doors, windows and doorsteps as well as polishing the floor. These were used for parapsychological purposes, and the effectiveness of their modes of administration is based on cultural beliefs. None of these findings mentioned above have been recorded in the literature to date.

\subsection{Plant Collection}

\subsubsection{Source}

It was noted that over half of the participants sourced material from muthi traders $(59.01 \%)$. This was expected as several studies have indicated that some of the investigated species, especially A. amatymbica [19], B. zanguebarica [20], D. sanguinea [40], S. aethiopicus and $W$. salutaris [23], have either become rare in collection sites or the distances to the collection sites are greater than in the past, and the majority of users now rely on muthi traders for supply. Muthi traders do not mind spending many hours searching for species and travelling longer distances for collections as they are interested in profit. A large percentage of participants (39.50\%) harvested the selected species from the wild (communal areas), which might be perceived as an indication that the availability, and thus abundance, of some of these species varies among locations.

Only $1.49 \%$ of participants were engaged in the cultivation of some of the species. Although Drimia sanguinea was generally collected from the communal areas, some effort by THPs $(16 \%)$ and CMs $(12 \%)$ in Capricorn, and THPs in Waterberg $(3 \%)$, went into cultivating it in home gardens. Participants who cultivated this species mentioned that they prefer using it in its fresh state and thus it was necessary to have it in close proximity. According to Semenya and Potgieter [45], it was indicated that cultivation of Drimia species (D. elata) is important for emergency purposes, showing that cultivation of Drimia species is not for conservation purposes but for personal benefits. In general, the low effort of participants to cultivate the investigated species calls for their education with regards to both the advantage and benefits of cultivation.

\subsubsection{Perception on Local Availability}

Participants' perceptions of the species availability varied between and even within the same area of collection. This was probably due to different specific locations of collection in the same area. Different perceptions regarding the availability of a species was also reported by Moeng [19] for the Limpopo Province. However, the actual status of the plants can only be determined by a scientific assessment of the population status in the collection area.

\section{Conclusions}

The use of the investigated TOPS-listed species is very common amongst THPs and $\mathrm{CMs}$ residing in different districts of the Limpopo Province. The many new medicinal uses documented by this study show that these species are over-harvested. This is especially 
true and will continue since applications of some of them are supported by scientific proofs, meaning they are effective. Furthermore, the largest utilization category of diseases treated with the investigated species was that of parapsychological problems, with their effectiveness based mostly on cultural belief, which is rooted in most South Africans. This will further exacerbate their harvesting pressure in the wild habitants of Limpopo Province and muthi shops (who the owners probably relies on these habitats) are the main sources of the investigated species in Limpopo Province, which will results in their extinction in the wild. It is therefore recommended that users of the species be educated about the danger of relying on the wild habitats and muthi shops for species. Futhermore, users be informed about the use of alternative parts, rather than underground ones for sustainability.

Author Contributions: Conceptualization, M.P. (Michèle Pfab); methodology, M.R.; validation, M.P. (Martin Potgieter) and M.P. (Michèle Pfab); formal analysis, M.R.; investigation, M.R.; resources, M.P. (Michèle Pfab); data curation, M.R.; writing—original draft preparation, M.R.; writing-review and editing, M.P. (Martin Potgieter) and M.P. (Michèle Pfab), supervision, M.P. (Martin Potgieter) and M.P. (Michèle Pfab); project administration, M.R.; funding acquisition, M.P. (Michèle Pfab). All authors have read and agreed to the published version of the manuscript.

Funding: This research was funded by South African National Biodiversity Institute (SANBI).

Institutional Review Board Statement: The study was conducted according to the guidelines of the Declaration of Helsinki, and approved by the Ethics Committee of the University of Limpopo.

Informed Consent Statement: Informed consent was obtained from all subjects involved in the study.

Data Availability Statement: Publicly available datasets of this study are available online at: http:/ / opus.sanbi.org/bitstream/20.500.12143/6349/1/Rasethe_2017_MSc_UL.pdf (accessed on 14 February 2021).

Acknowledgments: The authors are grateful to all participants who shared their valuable knowledge on the use of the selected TOPS-listed species in the Limpopo Province, South Africa. Thanks to the late Sebua Semenya for his assistance in data collection and Bronwyn Egan for editing this manuscript.

Conflicts of Interest: The authors declare no conflict of interest.

\section{References}

1. Van der Merwe, D.; Swan, G.E.; Botha, C.J. Use of ethnoveterinary medicinal plants in cattle by Setswana-speaking people in the Madikwe area of the North West Province of South Africa. J. S. Afr. Vet. Assoc. 2001, 72, 189-196. [CrossRef]

2. Sobiecki, J.F. The intersection of culture and science in South African traditional medicine. Indo-Pac. J. Phenom 2014, 14, 1-10. [CrossRef]

3. Ross, E. Inaugural lecture: African spirituality, ethics and traditional healing-implications for indigenous South African social work education and practice. S. Afr. J. Bioeth. Law 2010, 3, 44-51.

4. Makunga, N.P. African medicinal flora in the limelight. S. Afr. J. Sci. 2011, 107, 12. [CrossRef]

5. Mongalo, N.I. Antibacterial Activities of Selected Medicinal Plants Used to Treat Sexually Transmitted Infections in Blouberg Area, Limpopo Province. Master's Thesis, University of Zululand, KwaZulu-Natal, South Africa, 2013.

6. Mothibe, M.E.; Sibanda, M. African Traditional Medicine: South African Perspective. In Traditional and Complementary Medicine; Mordeniz, C., Ed.; IntechOpen: London, UK, 2019. [CrossRef]

7. Makueti, J.T.; Tsobeng, A.; Tchoundjeu, Z.; Tsafack, S.; Numbissi, F. Population structure and traditional management patterns of two threatened medicinal tree species (Garcinia lucida and Pausinystalia johimbe) in the humid southern forest of Cameroon. J. Biodivers. Environ. Sci. 2015, 7, 459-481.

8. Semenya, S.S.; Maroyi, A. Ethnobotanical survey of plants used by Bapedi traditional healers to treat tuberculosis and its opportunistic infections in the Limpopo Province, South Africa. S. Afr. J. Bot. 2019, 122, 401-421. [CrossRef]

9. Semenya, S.S.; Potgieter, M.J.; Erasmus, L.J.C. Indigenous plant species used by Bapedi healers to treat sexually transmitted infections: Their distribution, harvesting, conservation and threats. S. Afr. J. Bot. 2013, 87, 66-75. [CrossRef]

10. Semenya, S.S. Bapedi Phytomedicine and Their Use in the Treatment of Sexually Transmitted Diseases in Limpopo Province, South Africa. Master's Thesis, University of Limpopo, Mankweng, South Africa, 2012.

11. Mathibela, K.M. An Investigation into Aspects of Medicinal Plant Use by Traditional Healers from Blouberg Mountain, Limpopo Province, South Africa. Master's Thesis, University of Limpopo, Mankweng, South Africa, 2013.

12. Semenya, S.S.; Potgieter, M.J.; Tshisikhawe, M.P. Use, conservation and present availability status of ethnomedicinal plants of Matebele-village in the Limpopo Province, South Africa. Afr. J. Biotechnol. 2013, 12, 2393-2405. 
13. Mucina, L.; Rutherford, M.C. The Vegetation of South Africa, Lesotho and Swaziland; Strelizia 19, South African National Biodiversity Institute Pretoria: Silverton, CO, USA, 2006; 807p.

14. Neto, E.M.F.; Peroni, N.; Albuquerque, U.P. Traditional knowledge and management of umbu (Spondias tuberosa, Anacardiaceae): An endemic species from semi-arid region of north-eastern Brazil. Econ. Bot. 2010, 64, 11-21. [CrossRef]

15. Red List of South African Plants Version 2020.1. Available online: http:/ / redlist.sanbi.org/ (accessed on 15 September 2021).

16. Hutchings, A. A survey and-analysis of traditional medicinal plants as used by the Zulu, Xhosa and Sotho. Bothalia 1989, 19, 111-123. [CrossRef]

17. Quinlan, M.B. Considerations for collecting freelists in the field: Examples from ethnobotany. Field Methods 2005, 17, 1-16. [CrossRef]

18. Pérez-Vicente, S.; Ruiz, M.E. Descriptive statistics. Allergol. Immunopathol. 2009, 37, 314-320. [CrossRef]

19. Moeng, T.E. An Investigation into the Trade of Medicinal Plants by Muthi Shops and Street Vendors in the Limpopo Province, South Africa. Master's Thesis, University of Limpopo, Mankweng, South Africa, 2010.

20. Tshisikhawe, M.P.; Van Rooyen, M.W.; Bhat, R.B. An evaluation of the extent and threat of bark harvesting of medicinal plant species in the Venda region, Limpopo Province, South Africa. Int. J. Exp. Bot. 2012, 81, 89-100.

21. Magwede, K.; Van Wyk, B.-E.; Van Wyk, A.E. An inventory of Vhavenda useful plants. S. Afr. J. Bot. 2019, 122, 57-89. [CrossRef]

22. Hulela, K.; Thobega, M. Botswana faith leaders' attitudes towards the use of indigenous medicinal herbs. J. Med. Plants Res. 2013, 7, 1550-1556.

23. Maroyi, A. Warburgia salutaris (Bertol. f.) Chiov.: A multi-use ethnomedicinal plant species. J. Med. Plants Res. 2013, 7, 53-60.

24. Rasethe, M.T.; Semenya, S.S.; Maroyi, A. Medicinal Plants Traded in Informal Herbal Medicine Markets of the Limpopo Province, South Africa. Evid. Based Complement. Alternat. Med. 2019, 2019, 2609532. [CrossRef]

25. Komoreng, L.; Thekisoe, O.; Lehasa, S.; Tiwani, T.; Mzizi, N.; Mokoena, N.; Khambule, N.; Ndebele, S.; Mdletshe, N. An ethnobotanical survey of traditional medicinal plants used against lymphatic filariasis in South Africa. S. Afr. J. Bot. 2017, 111, 12-16. [CrossRef]

26. Philander, L.A. An ethnobotany of Western Cape Rasta bush medicine. J. Ethnopharmacol. 2011, 138, 578-594. [CrossRef] [PubMed]

27. Kelmanson, J.E.; Jager, A.K.; Van Staden, J. Zulu medicinal plants with antibacterial activity. J. Ethnopharmacol. 2000, 69, 241-246. [CrossRef]

28. Cogne, A.-L.; Marston, A.; Mavi, S.; Hostettmann, K. Study of two plants used in traditional medicine in Zimbabwe for skin problems and rheumatism: Dioscorea sylvatica and Urginea altissima. J. Ethnopharmacol. 2001, 75, 51-53. [CrossRef]

29. Motlhanka, D.M.T.; Nthoiwa, G.P. Ethnobotanical survey of medicinal plants of Tswapong North, in Eastern Botswana: A case of plants from Mosweu and Seolwane villages. Eur. J. Med. Plants 2013, 3, 10-24. [CrossRef]

30. Rankoana, S.A. Sustainable Use and Management of Indigenous Plant Resources: A Case of Mantheding Community in Limpopo Province, South Africa. Sustainability 2016, 8, 221. [CrossRef]

31. John, W.K. A Survey of Traditional Health Remedies Used by the Maasai of Southern Kaijiado District, Kenya. Ethnobot. Res. Appl. 2006, 4, 061-073.

32. Senkoro, A.M.; Talhinhas, P.; Simões, F.; Batista-Santos, P.; Shackleton, C.M.; Voeks, R.A.; Marques, I.; Ribeiro-Barros, A.I. The genetic legacy of fragmentation and overexploitation in the threatened medicinal African pepper-bark tree, Warburgia salutaris. Sci. Rep. 2020, 10, 19725. [CrossRef] [PubMed]

33. Marx, J.; Pretorius, E.; Espang, W.J.; Bester, M.J. Urginea sanguinea: Medicinal wonder or death in disguise? Environ. Toxicol. Pharmacol. 2005, 20, 26-34. [CrossRef] [PubMed]

34. Phanuel, A.S.; Nyunja, R.O.; Onyango, J.C. Plant species in the folk medicine of Kit Mikayi Region, Western Kenya. Ethnobot. Leaflets 2010, 14, 836-840.

35. Omoruyi, B.E.; Bradley, G.; Afolayan, A.J. Ethnomedicinal survey of medicinal plants used for the management of HIV/AIDS infection among local communities of Nkonkobe Municipality, Eastern Cape, South Africa. J. Med. Plants Res. 2012, 6, 3603-3608. [CrossRef]

36. Semenya, S.S.; Maroyi, A. Source, harvesting, conservation status, threats and management of indigenous plant used for respiratory infections and related symptoms in the Limpopo Province, South Africa. Biodiversitas 2019, 20, 790-811. [CrossRef]

37. Maroyi, A. Ethnobotanical study of two threatened medicinal plants in Zimbabwe. Int. J. Biodivers. Sci. Manag. 2008, 4, 148-153. [CrossRef]

38. Wintola, O.A.; Afolayan, A.J. Ethnobotanical survey of plants used for the treatment of constipation within Nkonkobe Municipality of South Africa. Afr. J. Biotechnol. 2010, 9, 7767-7770. [CrossRef]

39. Semenya, S.S.; Mokgoebo, M.J. The Utilization and Conservation of Indigenous Wild Plant Resources in the Limpopo Province, South Africa. In Natural Resources Management and Biological Sciences; Rhodes, E.R., Naser, H., Eds.; IntechOpen: London, UK, 2020. [CrossRef]

40. Stoffersen, A.; Winstrup, M.; Nieminen, R.; Allerton, T. Medicinal Plants and Traditional Healing in Contemporary Rural South Africa: The sustainability of Medicinal Plant Use in the Local Culture in Ongeluksnek, Eastern Cape, South Africa; Report from Faculty of Life Sciences; University of Copenhagen: Copenhagen, Denmark, 2011.

41. Ribeiro, A.; Romeiras, M.M.; Tavares, J.; Faria, M.T. Ethnobotanical survey in Canhane village, district of Massingir, Mozambique: Medicinal plants and traditional knowledge. J. Ethnobiol. Ethnomed. 2010, 6, 33-40. [CrossRef] 
42. Setsogo, M.P.; Mbereki, C.M. Floristic diversity and uses of medicinal plants sold by street Vendors in Gaborone, Botswana. Afr. J. Plant Sci. Biotechnol. 2011, 5, 69-74.

43. Jeruto, P.; Mutai, C.; George, O.; Lukhoba, C.; Nyamaka, R.; Manani, S.D. Ethnobotanical survey and propagation of some endangered medicinal plants from south Nandi district of Kenya. J. Anim. Plant Sci. 2010, 8, 1016-1043.

44. Van Wyk, A.S.; Prinsloo, G. Medicinal plant harvesting, sustainability and cultivation in South Africa. Biol. Conserv. 2018, 227, 335-342. [CrossRef]

45. Semenya, S.S.; Potgieter, M.J. Medicinal plants cultivate in Bapedi traditional healers homegardens, Limpopo Province, South Africa. Afr. J. Tradit. Complement. Altern. Med. 2014, 11, 126-132. [CrossRef] [PubMed] 